\title{
Selective citation and its consequences
}

Citation for published version (APA):

Urlings, M. J. E. (2019). Selective citation and its consequences. [Doctoral Thesis, Maastricht University]. ProefschriftMaken Maastricht. https://doi.org/10.26481/dis.20190703mu

Document status and date:

Published: 01/01/2019

DOI:

10.26481/dis.20190703mu

Document Version:

Publisher's PDF, also known as Version of record

\section{Please check the document version of this publication:}

- A submitted manuscript is the version of the article upon submission and before peer-review. There can be important differences between the submitted version and the official published version of record.

People interested in the research are advised to contact the author for the final version of the publication, or visit the DOI to the publisher's website.

- The final author version and the galley proof are versions of the publication after peer review.

- The final published version features the final layout of the paper including the volume, issue and page numbers.

Link to publication

\footnotetext{
General rights rights.

- You may freely distribute the URL identifying the publication in the public portal. please follow below link for the End User Agreement:

www.umlib.nl/taverne-license

Take down policy

If you believe that this document breaches copyright please contact us at:

repository@maastrichtuniversity.nl

providing details and we will investigate your claim.
}

Copyright and moral rights for the publications made accessible in the public portal are retained by the authors and/or other copyright owners and it is a condition of accessing publications that users recognise and abide by the legal requirements associated with these

- Users may download and print one copy of any publication from the public portal for the purpose of private study or research.

- You may not further distribute the material or use it for any profit-making activity or commercial gain

If the publication is distributed under the terms of Article $25 \mathrm{fa}$ of the Dutch Copyright Act, indicated by the "Taverne" license above, 

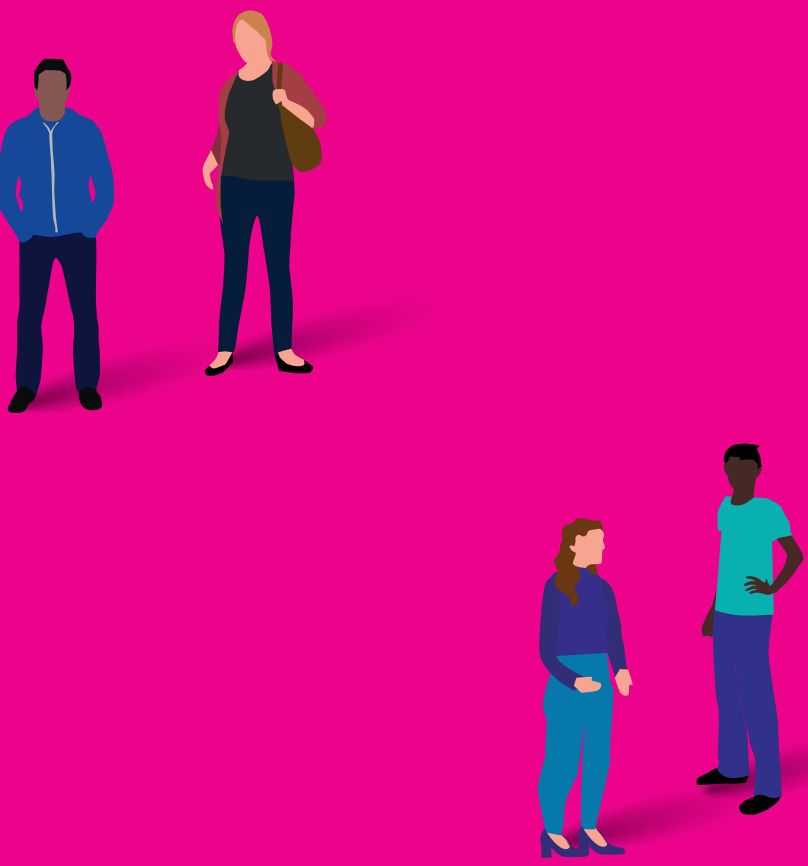

Summary 

This dissertation studied the occurrence of biases in the reporting of scientific research and addressed its potential impact on knowledge development and science-based decision making. Scientific publications are still the main form of communication among scientists in the development of knowledge. Biases in this process of publishing can be rather subtle, but of high impact on the development of knowledge. Chapter 2 described a case study on outcome reporting studying protocol adherence and selective reporting in scientific publications on phthalates. Use of study protocols is important in interpreting research findings and to prevent reporting of false positive outcomes. Unfortunately, we found that many research projects were performed without the use of a study protocol. Furthermore the willingness to share available study protocols was surprisingly low. As a result, it was impossible to compare the initial analysis plan with the reported findings and the occurrence of outcome reporting bias could not be tested. Additional to outcome reporting bias, this dissertation studied the occurrence of citation bias. Specifically, citation bias means the chance of being cited depends on the study outcome. Mostly this means that positive studies are cited more than negative studies. In chapter 3, we started with a systematic review and meta-analysis to map what is already known. We learned that evidence for the existence of citation bias has been found in multiple research fields. Additionally, we learned that many different methods were used to study citation bias. We have aimed to develop a new citation analysis methods, learning from earlier methods. With this citation analyses method we did not only study citation bias, but also looked at other potential determinants of selective citation. In chapters 4, 5 and 6 our citation analysis was applied to various research fields, namely the relationship between trans fatty acid intake and serum LDLand HDL-cholesterol, epidemiological studies on phthalates and epidemiological studies on bisphenol A. The networks included all relevant scientific publications in each field, identified via a systematic search. The citation network analyses answered two questions: "Does citation bias occur?" and "Which other determinants influence the likelihood of citation?". Apart from study outcome, the following determinants were tested: study design, sample size, number of affiliations, funding source, gender and affiliation of the corresponding author, journal impact factor, number of references, authority of the author and self-citation.

The three networks showed clearly distinguishing charactistics, which made it challenging to use the exact same method and compare the results. For example, the literature on trans fatty acids and serum cholesterol was largely influenced by one empirical publication, while the majority of the literature consisted of review articles. This network showed the strongest evidence for citation bias, with positive studies being three times more likely to be cited compared to negative studies.

In the networks on phthalates and bisphenol A many health outcomes were discussed. A strong public opinion consists on these two topics, where they are considered endocrine disruptors. Nevertheless, this opinion was not directly reflected in the scientific literature. For example, in the network on phthalates, a large proportion of the 
studies did not come to a purely positive or negative conclusion. These studies, showing mixed results, can be cited both as support for a harmful and for a safe effect on human health. Unfortunately, in the current analysis, these different interpretations could not be detected. No clear evidence for the existence of citation bias was found in this network.

In the network on bisphenol A, it was remarkable that the reported results and the authors' conclusion were not always coherent. Because many publications described multiple health outcomes, they often reported both significant and non-significant findings. Nevertheless, the vast majority of these publications ultimately concluded that a harmful effect on human health exists. Evidence for citation bias was found in the network on BPA, but with a smaller magnitude of 1.5 times more chance of citation for positive studies compared to negative studies.

The three citation analyses presented in this dissertation were part of a bigger project, named the Sound Science project. Within the Sound Science project three additional citation analyses were performed. These involved the following subjects: the relationship between swimming in chlorinated water and childhood asthma, the hygiene hypothesis and the relationship between diesel emission and lung cancer in humans. Although each citation network analysis is merely a case study, by performing a total of six of these case studies we aimed to look for patterns and to distinguish between general and field-specific determinants of citation. Evidence for citation bias was found in four out of six networks, with varying magnitudes. With regard to other factors that might impact the chance of citation, we found journal impact factor, authority of the author and self-citation as general determinants of citation. Also the quality-related determinants study design and sample size showed a consistent association with citation. However, for study design the observed effect was different than expected, with empirical studies being more likely to be cited compared to review articles.

In chapter 7 we stepped outside of the scientific community and assessed selection bias in risk assessment as performed by the European Food Safety Authority (EFSA). This risk assessment functions as the basis for policy decisions by the European Commission. Basic principles of EFSA are to conduct a risk assessment in an objective, independent and transparent manner. In this context, much attention is going to financial and political conflicts of interest. In this dissertation, we address the problem of scientific independence and corresponding intellectual conflict of interest. Scientists can have such conflict of interest, because of experience in a certain field and because they interpret evidence in light of their own discipline. Selective use of evidence in risk assessment can jeopardize EFSA's core values of independence and objectivity and directly lead to decisions that are not evidence-based. To assess the objectivity within the risk assessment, we performed a case study on the risk assessment on bisphenol A. The literature on BPA identified in the earlier performed citation analysis was compared to the literature that was used in the risk assessment on BPA. Out of 36 available publications, 30 were 
included in the risk assessment. No reason was given for the exclusion of the other publications, although this might have been because of their cross-sectional nature.

Overall, we can conclude from this dissertation that scientific reporting can be distorted in different ways, with more and less serious consequences. Selective use of citations has shown to be associated with a number of determinants, among which is study outcome, but also more acceptable determinants such as sample size and authority of the author. Increasing transparency, for example by publishing study protocols, and reducing citation bias will increase the validity and credibility of science-based decisions, both within and outside of academia, such as in policy-making and development of clinical therapies. 



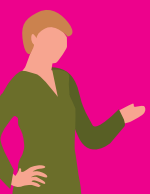

II

\section{Nederlandse \\ samenvatting}





\section{Selectieve citatie en diens gevolgen}

Deze dissertatie bestudeerde het vóórkomen van vertekening in het rapporteren van wetenschappelijk onderzoek en beschreef de mogelijke invloed hiervan op kennisontwikkeling en empirisch onderbouwde besluitvorming. Wetenschappelijke publicaties zijn nogsteeds de voornaamste vorm van communicatie tussen wetenschappers in de ontwikkeling van kennis. Op zeer subtiele wijze kan er vertekening in deze communicatie optreden, welke veel invloed heeft op de ontwikkeling van kennis. Hoofdstuk 2 beschrijft een case studie over zogenaamde outcome reporting bias in de literatuur naar phthalaten. Outcome report bias refereert aan het selectief rapporteren van onderzoeksresultaten in een publicatie, waarbij ongewenste resultaten worden weggelaten. In de case studie onderzoeken we de naleving van studie protocollen en vergelijken dit met de achteraf gerapporteerde studie uitkomsten. Het gebruik van studie protocollen is van belang bij het interpreteren van studie resultaten en om het rapporteren van vals-positieve resultaten te voorkomen. Helaas hebben we gevonden dat veel onderzoeksprojecten zijn uitgevoerd zonder gebruik te maken van een vooraf opgesteld onderzoeksprotocol. Daarnaast was de bereidwilligheid van onderzoekers om hun studie protocol te delen verrassend laag. Als gevolg daarvan was het onmogelijk om de vooraf geplande analyse te vergelijken met de gerapporteerde studie resultaten en het vóórkomen van outcome reporting bias kon niet worden vastgesteld.

Naast outcome reporting bias bestudeerde deze dissertatie het vóórkomen van citatiebias. Specifiek betekent citatiebias dat de kans om geciteerd te worden samenhangt met de uitkomst van de studie. Meestal betekent dit dat positieve studies een grotere kans hebben om geciteerd te worden in vergelijking met negatieve studies. In hoofdstuk 3 zijn we gestart met een systematische review en meta-analyse om een overzicht te geven van wat er al bekend is over dit onderwerp. Hierbij hebben we geconstateerd dat citatiebias is onderzocht en aangetoond in verschillende wetenschappelijke vakgebieden. Daarnaast hebben we gevonden dat er veel verschillende methoden werden gebruikt om citatiebias te onderzoeken. Wij hebben ons tot doel gesteld een nieuwe methode te ontwikkelen, waarbij we geleerd hebben van eerdere studies. Met onze nieuwe methode hadden we niet alleen ten doel citatiebias te onderzoeken, maar ook inzicht te krijgen in andere determinanten van citatie. In hoofdstukken 4, 5 en 6 hebben we onze citatie netwerk analyse toegepast op drie verschillende wetenschappelijke velden, namelijk de relatie tussen transvetten en LDL- en HDL-cholesterol, epidemiologische studies over phthalaten en epidemiologische studies over bisphenol A. leder netwerk omvatte alle relevante wetenschappelijke publicaties in het betreffende veld, die geidentificeerd waren via een systematische zoekstrategie. De citatie netwerk analyse werd gebruikt om twee vraagstellingen te beantwoorden: "Is er sprake van citatiebias?" en "Welke andere determinanten beinvloeden de kans op citatie?". Naast studie uitkomst werden de volgende determinanten onderzocht: studie design, aantal deelnemers in een onderzoek, aantal affiliaties, onderzoeksfinancier, geslacht en affiliatie 
van de auteur, impact factor van het tijdschrift, aantal referenties in een publicatie, autoriteit van de auteur en zelf-citatie.

De drie onderzochte netwerken lieten duidelijke verschillen zien, waardoor het lastig was één methode toe te passen op ieder onderwerp en om de resultaten te vergelijken. In de literatuur over transvetten en cholesterol was bijvoorbeeld sterk beinvloed door één publicatie, terwijl de meerderheid van de publicaties bestond uit samenvattende publicaties. Dit netwerk liet het sterkte bewijs voor citatiebias zien, waarbij positieve studies een drie keer zo grote kans hadden om geciteerd te worden in vergelijking met negatieve studies.

In de netwerken over phthalaten en bisphenol A werden er meerdere gezondheidsuitkomsten onderzocht. Beide onderwerpen kennen een sterk publiek debat, waarbij wordt gesteld dat beide stoffen een hormoonverstorende werking hebben. Deze visie is echter niet zonder meer ondersteund in de wetenschappelijke literatuur. In de literatuur naar phthalaten, bijvoorbeeld, kwam een groot deel van de publicaties niet tot een duidelijke positieve of negatieve conclusie. Deze studies, met gemixte resultaten, kunnen zowel als schadelijk en onschadelijk voor de menselijke gezondheid aangehaald worden in een citatie. In de huidige onderzoeksmethode hebben we helaas geen rekening kunnen houden met deze verschillen in interpretatie. Er was geen duidelijk bewijs voor citatiebias in dit netwerk gevonden.

In het netwerk over bisphenol A was het vooral opvallend dat de gerapporteerde resultaten en bijbehorende auteurs' conclusie niet altijd overeen kwamen. Doordat veel publicaties meerdere gezondheidsuitkomsten beschreven bevatten de meeste studies zowel significante als niet-significante resultaten. De meerderheid van studies komt echter wel tot de conclusie dat bisphenol A schadelijk is voor de gezondheid. In het netwerk van bisphenol A werd er bewijs gevonden voor de aanwezigheid van citatiebias, waarbij positieve studies een anderhalf keer grotere kans hebben om geciteerd te worden dan negatieve studies.

De drie citatie analyses die gepresenteerd werden in dit proefschrift zijn onderdeel van een groter project, genaamd het Sound Science project. Binnen het Sound Science project zijn er nog drie andere netwerk analyses uitgevoerd. De onderwerpen hiervan zijn als volgt: de relatie tussen zwemmen in gechloreerd water en de ontwikkeling van astma bij kinderen, de hygiene hypothese en de relatie tussen dieseluitstoot en longkanker bij mensen. Hoewel ieder netwerk slecht een casus beschrijft, hebben we geprobeerd een patroon te herkennen en onderscheid te maken tussen algemene en casus-specifieke kenmerken van citatie door zes casussen te onderzoeken. In vier van de zes netwerken werd er, in verschillende mate, bewijs gevonden voor het bestaan van citatiebias. Wat betreft andere mogelijke determinanten van citatie, werden de impact factor van het tijdschrift, de autoriteit van de auteurs en zelf-citatie als algemeen geldende determinanten van citatie gevonden. Daarnaast werden kwaliteit-gerelateerde determinanten zoals het aantal deelnemers per studie consistent als determinant van citatie gevonden. Wat betreft studie design was de relatie met de kans op citatie anders 
dan verwacht, hierbij was de kans op citatie groter voor empirische studies in vergelijking met samenvattende studies.

In hoofdstuk 7 zijn we uit de wetenschappelijke context gestapt en keken we naar citatiebias in de risicobeoordeling door de Europese Voedselveiligheid Authoriteit (EFSA). Deze risicobeoordeling functioneert als de basis van beleidsbeslissingen door de Europese Commissie. Basisprincipes in deze wetenschappelijke risicobeoordeling zijn dat het op een objectief, onafhankelijk en transparante manier wordt uitgevoerd. In deze context is er tot nu toe veel aandacht voor financiele en politieke belangenverstrengeling. Dit proefschrift benoemt echter het probleem van wetenschappelijke onafhankelijkheid en bijbehorende intellectuele belangenverstrengeling. Wetenschappers kunnen last hebben van deze belangenverstrengeling, vanwege hun ervaring in één bepaald vakgebied. Daardoor kunnen ze bevindingen interpreteren in het licht van hun eerdere ervaringen, in plaats van er geheel objectief naar te kijken. Selectief citeren van bewijs in de risicobeoordeling van EFSA brengt echter de basis waarden van onafhankelijkheid en objectiviteit in gevaar en leidt daarmee tot beslissingen die niet gebasseerd zijn op al het beschikbare empirische bewijs. Om de objectiviteit in de risicobeoordeling te onderzoeken hebben we een case studie gedaan naar de risicobeoordeling van EFSA naar bisphenol A. De wetenschappelijke literatuur over bisphenol A, die was verzameld in het kader van de eerder uitgevoerde citatie analyse, werd vergeleken met de literatuur die gebruikt was in de risicobeoordeling door EFSA. Van de 36 beschikbare empirische studies, waren er 30 meegenomen in de risicobeoordeling. Er werd geen reden gegeven voor het excluderen van de overige zes publicaties, hoewel dit wellicht is toe te schrijven aan het dwarsdoorsnede onderzoeksdesign.

Concluderend uit dit proefschrift kunnen we stellen dat rapportage van wetenschappelijk onderzoek op verschillende manieren vertekend kan worden, waarvan de consequenties in meer of mindere mate problematisch zijn. Selectief gebruik van citaties is gerelateerd gebleken aan een aantal verschillende factoren, waaronder studie uitkomst, maar ook meer acceptabele determinanten zoals studie design en de authoriteit van de auteurs. Vergroten van transparantie, bijvoorbeeld door het publiceren van studie protocollen, en reduceren van citatiebias zal de validiteit en betrouwbaarheid van wetenschappelijke besluitvorming vergroten, zowel binnen als buiten de wetenschap, zoals in beleid maken en ontwikkeling van klinische therapieën. 